This document is the accepted manuscript version of the following article:

Schlupp, M. V. F., Kim, J. W., Brevet, A., Rado, C., Couturier, K., Vogt, U. F., ... Zütte1, A. (2014). Avoiding chromium transport from stainless steel interconnects into contact layers and oxygen electrodes in intermediate temperature solid oxide electrolysis stacks. Journal of Power Sources, 270, 587-593. https://doi.org/10.1016/j.jpowsour. 2014.07.094

This manuscript version is made available under the CC-BY-NC-ND 4.0 1icense http://creativecommons.org/1icenses/by-nc-nd/4.0/

\title{
Avoiding chromium transport from stainless steel interconnects into contact layers and oxygen electrodes in intermediate temperature solid oxide electrolysis stacks
}

\begin{abstract}
Meike V. F. Schlupp ${ }^{\mathrm{a}, *}$, Ji Woo Kim ${ }^{\mathrm{a}}$, Aude Brevet ${ }^{\mathrm{b}}$, Cyril Rado ${ }^{\mathrm{b}}$, Karine Couturier $^{\mathrm{b}}$, Ulrich F. Vogt ${ }^{\mathrm{a}, \mathrm{c}}$, Florence Lefebvre-Joud ${ }^{\mathrm{b}}$, Andreas Züttel ${ }^{\mathrm{a}}$,

${ }^{a}$ Laboratory for Hydrogen and Energy, Swiss Federal Laboratories for Materials Science and Technology (EMPA), 8600 Dübendorf, Switzerland

${ }^{b}$ Laboratory for Innovation in New Energy Technologies and Nanomaterials (LITEN), Commissariat à l'énergie atomique et aux énergies alternatives (CEA), 38054 Grenoble, France

${ }^{c}$ Crystallography, Institute of Earth and Environmental Science, Albert-Ludwigs-University of Freiburg, Germany
\end{abstract}

\begin{abstract}
We investigated the ability of $\left(\mathrm{La}_{0.8} \mathrm{Sr}_{0.2}\right)\left(\mathrm{Mn}_{0.5} \mathrm{Co}_{0.5}\right) \mathrm{O}_{3-\delta}$ (LSMC) and $\mathrm{La}\left(\mathrm{Ni}_{0.6} \mathrm{Fe}_{0.4}\right) \mathrm{O}_{3-\delta}$ (LNF) contact coatings to avoid the transport of Cr from steel interconnects to solid oxide electrolysis electrodes, especially to the anode. The transport of chromium from commercial Crofer 22 APU (ThyssenKrupp) and K41X (AISI441, Aperam Isbergues) steels through LSMC and LNF contact coatings into adjacent $\left(\mathrm{La}_{0.8} \mathrm{Sr}_{0.2}\right) \mathrm{MnO}_{3-\delta}$ (LSM) oxygen electrodes was investigated in an oxygen atmosphere at $700^{\circ} \mathrm{C}$. Chromium concentrations of up to 4 atom $\%$ were detected in the contact coatings after thermal treatments for $3000 \mathrm{~h}$, which also lead to the presence of chromium in adjacent LSM electrodes. Introduction of a dense $(\mathrm{Co}, \mathrm{Mn})_{3} \mathrm{O}_{4}$ coating between steel and contact coating was necessary to prevent the diffusion of chromium into contact coatings and electrodes and should lead to extended stack performance and lifetime.
\end{abstract}

Keywords: chromium poisoning, SOEC, interconnect, contact coating,

\footnotetext{
*Corresponding author

Email address: Meike.Schlupp@empa.ch (Meike V. F. Schlupp)
} 
diffusion barrier layer, spinel

\section{Introduction}

Based on their electrical conductivity, thermal expansion behavior, mechanical properties (formability, ease of fabrication, creep resistance) and low cost, ferritic stainless steels are suitable materials for interconnects in solid oxide fuel or electrolysis cells (SOFC, SOEC) operating at intermediate temperatures $\left(600^{\circ} \mathrm{C}-800^{\circ} \mathrm{C}\right)$. Besides distributing and separating the process gases on anode and cathode sides, interconnects are used for electrically connecting several cells in series in planar SOFC or SOEC stacks. As a consequence, their performance is influenced by surface properties, which are governed by the oxidation layers or scales which intrinsically form on ferritic stainless steels. In terms of surface stability and electrical conductivity, the commercial ferritic Fe-Cr-Mn alloys Crofer $22 \mathrm{APU}$ (22 wt\% Cr, ThyssenKrupp) and K41X (AISI441, 18 wt\% Cr, Aperam Isbergues) are promising and frequently studied SOFC/SOEC interconnect materials [1-5]. On thermal oxidation, these steels form protective, electrically conductive oxide scales comprised of $\mathrm{Cr}_{2} \mathrm{O}_{3}$ and $(\mathrm{Mn}, \mathrm{Cr})_{3} \mathrm{O}_{4}$ spinel [1, 3, 4, 6-9].

A problem associated with chromium scales, however, is the formation of volatile chromium species like $\mathrm{CrO}_{2}(\mathrm{OH})_{2}$ or $\mathrm{CrO}_{3}$ at elevated temperatures [10], which is significant for both $\mathrm{Cr}_{2} \mathrm{O}_{3}$ and $(\mathrm{Mn}, \mathrm{Cr})_{3} \mathrm{O}_{4}[6,11]$. These gaseous chromium species have a tendency to undergo electrochemical reduction to $\mathrm{Cr}_{2} \mathrm{O}_{3}$ at gas/oxygen electrode/electrolyte three-phase boundaries or to chemically react with the oxygen electrode materials, thus leading to the poisoning of SOFC or SOEC oxygen electrodes [10, 12-14]. To avoid performance degradation associated with chromium poisoning, steel interconnects are therefore often coated with protective layers $[5,8,11,15,16]$.

In this study, we investigate the transport of chromium from steel interconnects into porous contact coatings and adjacent oxygen electrodes under severe $\mathrm{SOE}$ conditions in dry oxygen atmosphere at $700^{\circ} \mathrm{C}$ for up to $3000 \mathrm{~h}$. The $\left(\mathrm{La}_{0.8} \mathrm{Sr}_{0.2}\right)\left(\mathrm{Mn}_{0.5} \mathrm{Co}_{0.5}\right) \mathrm{O}_{3-\delta}$ (LSMC) or $\mathrm{La}\left(\mathrm{Ni}_{0.6} \mathrm{Fe}_{0.4}\right) \mathrm{O}_{3-\delta}$ (LNF) contact coatings are originally applied to the steel interconnect to minimize the ohmic resistance to the oxygen electrode in SOEC stacks, providing a homogeneous contact over the whole cell area. In addition, they may also trap chromium by chemical reactions, thus acting as protective layers. Furthermore, the effect of a dense $(\mathrm{Co}, \mathrm{Mn})_{3} \mathrm{O}_{4}$ spinel layer deposited between steel 
surface and contact coating is investigated. Such $(\mathrm{Co}, \mathrm{Mn})_{3} \mathrm{O}_{4}$ spinels bond well to stainless steel substrates under thermal cycling $[2,17]$, feature a low electrical resistance [18], and have been shown to act as effective barriers to chromium outward migration $[2,8,18,19]$. We combine the microstructural evolution of contact layers and their interface to the steel interconnect after aging treatments representative of SOE anodic conditions with quantification of the chromium distribution in contact layers and analysis of chromium transported into adjacent SOE anodes.

\section{Experimental}

Specimens were prepared by coating square $10 \times 10 \mathrm{~mm}^{2}$ or $20 \mathrm{x} 20 \mathrm{~mm}^{2}$ stainless steel pieces of Crofer 22 APU (ThyssenKrupp, Germany) and K41X (Aperam Isbergues, France) of $1 \mathrm{~mm}$ thickness with a contact layer. For this, slurries were prepared from powders of $\left(\mathrm{La}_{0.8} \mathrm{Sr}_{0.2}\right)\left(\mathrm{Mn}_{0.5} \mathrm{Co}_{0.5}\right) \mathrm{O}_{3-\delta}(\mathrm{LSMC}$, Marion Technologies, France, $\mathrm{d}_{50}=0.33 \mu \mathrm{m}, \mathrm{d}_{90}=0.45 \mu \mathrm{m}$, specific surface area $\left.13.6 \mathrm{~m}^{2} \mathrm{~g}^{-1}\right)$ or $\mathrm{La}\left(\mathrm{Ni}_{0.6} \mathrm{Fe}_{0.4}\right) \mathrm{O}_{3-\delta}$ (LNF, Marion Technologies, France, $\mathrm{d}_{50}=0.46 \mu \mathrm{m}, \mathrm{d}_{90}=1.34 \mu \mathrm{m}$, specific surface area $\left.4.4 \mathrm{~m}^{2} \mathrm{~g}^{-1}\right)$ and a 5 mass $\%$ solution of ethyl cellulose in terpineol. Four layers were deposited on top of each other by screen printing on both faces of the steel substrates with a 150 mesh screen (with drying steps of $15 \mathrm{~min}$ at $110^{\circ} \mathrm{C}$ after each deposition to remove the solvent). For some samples - before deposition of the contact coatings - a $\mathrm{Co}_{2-x} \mathrm{Mn}_{1+x}$ metallic film was deposited on the steel substrates by magnetron sputtering (PVDco, France). This layer was then thermally oxidized into a $3-4 \mu \mathrm{m}$ thick dense $(\mathrm{Co}, \mathrm{Mn})_{3} \mathrm{O}_{4}$ layer in air for $10 \mathrm{~h}$ at $800^{\circ} \mathrm{C}$.

Annealing was performed in a tube furnace (Carbolite, UK) under pure

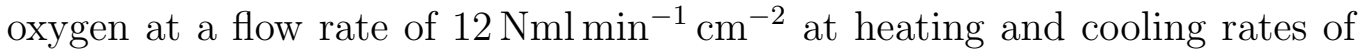
$5^{\circ} \mathrm{C} \mathrm{min}{ }^{-1}$. First, a pre-treatment was performed at $750^{\circ} \mathrm{C}$ for $2 \mathrm{~h}$ to simulate the procedure in single repeat units and stacks associated with the formation of glass sealants. The samples were then annealed at $700^{\circ} \mathrm{C}$ for $200 \mathrm{~h}$ or $3000 \mathrm{~h}$. For microstructural analyses of heat treated samples, polished cross sections were prepared after embedding in a mixture of Araldit BY 158 and Aradur 21 (Huntsman, USA) at a weight ratio of $4: 1$ by vacuum impregnation at 20 mbar and subsequent pressurization at 2 bars. A carbon coating was applied for scanning electron microscopy (SEM) and focused ion beam (FIB) applications. A Nova NanoSEM 230 microscope (FEI, USA) with Everhard-Thornley secondary electron (SE), solid state backscattered electron (BSE) and energy dispersive X-ray spectroscopy (EDS) detectors (X- 
Max, Oxford Instruments, UK) was used. EDS quantification was performed at $20 \mathrm{kV}$ using a copper calibration standard and the software Inca (Oxford Instruments, UK). Lamellae for transmission electron microscopy (TEM) and scanning transmission electron microscopy (STEM) were prepared by FIB (Nova 200, FEI, USA). The surfaces of the samples were protected by carbon and platinum depositions and lamellae were prepared by cutting and polishing trenches into the samples with $\mathrm{Ga}^{+}$ion beam currents down to $30 \mathrm{pA}$ or $50 \mathrm{pA}$ at $30 \mathrm{keV}$. Lift-outs of the lamellae to copper grids were performed using a manipulating probe (Omniprobe 100.7, Oxford Instruments, UK). For TEM analyses, a Tecnai F20 microscope (FEI, USA) was applied at $200 \mathrm{keV}$. Scanning transmission electron microscopy (STEM) images were collected using a high-angle annular dark field detector (HAADF). Chemical composition maps were obtained using energy dispersive spectroscopy (EDS) and energy-filtered transmission electron microscopy (EFTEM).

For chromium evaporation measurements, a new method based on the trapping of volatile $\mathrm{Cr}$ species emitted by the interconnect samples in an adjacent electrode material was designed in this study. This approach differs from the quantitative transpiration method broadly used for such studies $[20,21]$ with the aim to simultaneously test eight samples in one experiment. Bare or coated steel substrates of 20x20 $\mathrm{mm}^{2}$ (with a hole of $4 \mathrm{~mm}$ diameter, not required for evaporation testing but used for handling in case of oxidation testing) were placed into a custom-made quartz sample holder (see Figure 1). On top of the steel substrates, commercial solid oxide cells (ESC2, H. C. Starck) $25 \times 25 \mathrm{~mm}^{2}$ in size were placed with the $\left(\mathrm{La}_{0.8} \mathrm{Sr}_{0.2}\right) \mathrm{MnO}_{3-\delta}$ (LSM) electrodes facing the steel/ coating surface at a distance of $0.5 \mu \mathrm{m}$. This distance was optimized to allow a reasonable $\mathrm{Cr}$ concentration in the electrode material after $500 \mathrm{~h}$ of testing while preventing a physical contact with the interconnect. After annealing at $700^{\circ} \mathrm{C}$ in a static oxygen atmosphere for $500 \mathrm{~h}$, the solid oxide cell samples were dissolved in an acidic solution and analyzed for $\mathrm{Cr}$, La, $\mathrm{Sr}$ and Mn by inductively coupled plasma optical emission spectrometry (ICP-OES model 725, Agilent Technologies, USA). It should be noticed that the amount of Cr detected in LSM by this technique is linked to two phenomena: (i) $\mathrm{Cr}$ evaporation from interconnect materials, (ii) Cr trapping into LSM. For a given set of experiments carried out in identical conditions, i.e. in constant thermodynamical conditions, the $\mathrm{Cr}$ trapping into LSM may be inferred to only depend on the nature of the interconnect/ coating combinations and on their subsequent Cr evaporation rate. Thus the technique does allow a screening of the interconnect materi- 
als on their ability to reduce Cr evaporation towards the oxygen electrode. However, since not all volatile species are trapped by the electrode material of the adjacent cell, a certain base level of $\mathrm{Cr}$ is found in all specimens. An absolute quantification of the transport of $\mathrm{Cr}$ species from the interconnect material, and consequently the determination of the $\mathrm{Cr}$ evaporation rate, are thus not possible.

\section{Results and Discussion}

LSMC and LNF contact coatings on Crofer and K41X steels

On the surface of LSMC coated Crofer 22 APU, the formation of a Cr-rich scale of few hundred nanometers thickness is observed already after the initial heat treatment at $750^{\circ} \mathrm{C}$ for $2 \mathrm{~h}$ according to BSE images and EDS line scans of polished cross sections (not shown here). With further annealing at $700^{\circ} \mathrm{C}$ for $200 \mathrm{~h}$ and $3000 \mathrm{~h}$, the thickness of this scale increases. In addition, an interfacial layer as well as reaction zones within the LSMC contact layer appear. The partially idiomorphic grains of up to $5 \mu \mathrm{m}$ diameter below the steel surface (e.g. position 2 in Figure 2) are identified as cubic $\mathrm{Cr}_{2} \mathrm{MnO}_{4}$ spinel by electron diffraction. This is shown in more detail in the HAADF-STEM overview of a FIB section in Figure 2, which depicts the Crofer/LSMC interface after annealing at $700^{\circ} \mathrm{C}$ for $3000 \mathrm{~h}$. Along the steel/LSMC interface, the pore space around the LSMC grains is filled up by a crystalline solid phase (see position 3, Figure 2) within a layer of up to $1 \mu \mathrm{m}$ thickness. This layer is composed of LSMC particles surrounded by a Cr-Mn-Co-oxide, probably a $(\mathrm{Cr}, \mathrm{Mn}, \mathrm{Co})_{3} \mathrm{O}_{4}$ spinel (position b in Figure 3). Crofer $22 \mathrm{APU}$, which contains $0.3-0.8 \% \mathrm{Mn}[22]$, is known to form a scale layer composed of $\mathrm{Cr}_{2} \mathrm{MnO}_{4}$ spinel (due to $\mathrm{Mn}$ diffusion from the steel) and $\mathrm{Cr}_{2} \mathrm{O}_{3}[11,23]$. As a result of $\mathrm{Mn}$ and $\mathrm{Co}$ diffusion from the contact coating, however, the $\mathrm{Cr}_{2} \mathrm{O}_{3}$ scale is replaced by a Cr-Mn-Co-oxide at the Crofer/LSMC interface in our study. The presence of this additional Mn source is also expected to further promote the development of the $\mathrm{Cr}_{2} \mathrm{MnO}_{4}$ spinel phase, similar to results reported for LSM [11] and $(\mathrm{Mn}, \mathrm{Co})_{3} \mathrm{O}_{4}[9]$ on Crofer $22 \mathrm{APU}$. While the interfacial reaction layer at the Crofer/LSMC interface may positively affect adhesion of the contact coatings to the steel surface, $\mathrm{Cr}_{2} \mathrm{MnO}_{4}$ and $(\mathrm{Cr}, \mathrm{Mn}, \mathrm{Co})_{3} \mathrm{O}_{4}$ spinels feature rather low electrical conductivities in the order of $10^{-3} \mathrm{~S} \mathrm{~cm}^{-1}$ and $10^{0}-10^{1} \mathrm{~S} \mathrm{~cm}^{-1}$ at $700^{\circ} \mathrm{C}$, respectively [24-26]. Increased thicknesses of the

scale and interfacial layers due to diffusion of $\mathrm{Co}$ and $\mathrm{Mn}$ from the contact coating are thus expected to increase the contact resistance. 
Features with a solid phase filling up the pore space around particles are also observed in defined areas within the LSMC layer (e.g. position 5 in Figure 2). According to the EDS maps in Figure 4 and HR-TEM (not shown here), this phase corresponds to a crystalline Sr-Cr-oxide, most likely $\mathrm{SrCrO}_{4}$. The former LSMC particles in this area are depleted in $\mathrm{Sr}$ as compared to their original composition. These aggregates reach diameters of up to several micrometers and occur throughout the thickness of the coating, although they are larger within the first $15 \mu \mathrm{m}$ of the LSMC layer (see Figure 6 a). The reaction of chromium from the steel interconnect to $\mathrm{SrCrO}_{4}$ in the LSMC contact coating shows that mobile $\mathrm{Cr}$ species are transported through the whole coating even at a temperature of $700^{\circ} \mathrm{C}$ after $3000 \mathrm{~h}$. Besides compromising the electrical and ion conductivity of the Sr-depleted LSMC, these aggregates will negatively influence the gas transport properties of the contact coating. More importantly, LSMC is not able to effectively trap Cr over a longer period of time, so a poisoning of the adjacent oxygen electrode is expected. In solid oxide fuel cells, the formation of $\mathrm{SrCrO}_{4}$ is known to increase the polarization and/or ohmic resistance of oxygen electrodes like LSM [14] or $(\mathrm{La}, \mathrm{Sr})(\mathrm{Co}, \mathrm{Fe}) \mathrm{O}_{3}$ (LSCF) [27] leading to a decrease in the voltage output in single-cell stacks [28].

Similar results as on Crofer are also obtained for LSMC contact coatings on K41X steel, which forms a crystalline $\mathrm{Cr}_{2} \mathrm{O}_{3}$ scale. The presence of a $(\mathrm{Mn}, \mathrm{Cr})_{3} \mathrm{O}_{4}$ spinel scale was not detected for the given annealing conditions at $700^{\circ} \mathrm{C}$ for up to $3000 \mathrm{~h}$. At the $\mathrm{K} 41 \mathrm{X} / \mathrm{LSMC}$ interface, a $\mathrm{SrCrO}_{4}$-rich interfacial layer is observed on top of the $\mathrm{Cr}_{2} \mathrm{O}_{3}$ scale after the initial heat treatment at $750^{\circ} \mathrm{C}$ for $2 \mathrm{~h}$. Si is also present at the interface. With further annealing at $700^{\circ} \mathrm{C}$, aggregates with $\mathrm{SrCrO}_{4}$ surrounding former LSMC particles develop within the contact layer as described for LSMC on Crofer $22 \mathrm{APU}$. In contrast to Crofer $22 \mathrm{APU}$, however, delamination along the scale is frequently observed for LSMC contact coatings on K41X after $3000 \mathrm{~h}$ of annealing.

In LNF contact coatings on Crofer $22 \mathrm{APU}$, interfacial layers (apart from the $\mathrm{Cr}_{2} \mathrm{MnO}_{4}$ spinel scale), reaction zones or other obvious microstructural changes are not observed. This is also the case for LNF on K41X steel, although two oxide layers are detected at the interface to the steel on top of the $\mathrm{Cr}_{2} \mathrm{O}_{3}$ scale after $3000 \mathrm{~h}$ at $700^{\circ} \mathrm{C}$ in this sample, of which the bottom oxide layer contains $\mathrm{Cr}$ and $\mathrm{Si}$, while $\mathrm{La}$ and $\mathrm{Si}$ are found in the top oxide layer. In addition, delamination along the scale is observed for LNF on K41X after $3000 \mathrm{~h}$ of annealing. 
Despite the lack of microstructural indicators in LNF contact coatings, the presence of $\mathrm{Cr}$ is detected by EDS analyses in both LSMC and LNF layers on Crofer $22 \mathrm{APU}$ as well as on K41X steels. The Cr content in LNF contact layers on Crofer $22 \mathrm{APU}$ and K41X after $200 \mathrm{~h}$ of annealing is plotted in Figure $5 \mathrm{a}$ as a function of distance to the steel/ coating interface. While up to 3 atom $\% \mathrm{Cr}$ are detected close to the interface, its content decreases towards the outer parts of the contact coating. For distances higher than $60 \mu \mathrm{m}$ away from the steel surface, the $\mathrm{Cr}$ content is close to the detection limit. This indicates that the thickness of the contact coating is a key parameter to reduce the transport of chromium to the oxygen electrode in a given time frame. The distribution of $\mathrm{Cr}$ is very similar for both K41X and Crofer substrates, indicating that the formation of different scale layers on the steel surfaces of K41X and Crofer does not significantly influence the reaction of chromium species in the contact coating for an annealing time of $200 \mathrm{~h}$. The lack of microstructural changes in LNF contact coatings suggests the incorporation of Cr into the LNF particles and the formation of Cr-containing perovskites, which can result in even more severe degradation of the area specific resistance (ASR) in LNF than in LSMC contact layers according to literature [23].

After $3000 \mathrm{~h}$ of annealing, the $\mathrm{Cr}$ content is similar throughout the thickness of the contact coatings (taking into account inhomogeneities, e.g. the formation of $\mathrm{SrCrO}_{4}$-rich aggregates in the LSMC coatings, Figure 6 a). The presence of $2 \pm 1$ atom $\% \mathrm{Cr}$ is detected in a $\approx 25 \mu \mathrm{m}$ thick LSMC coating (Figure 6 a), while $3 \pm 1$ atom $\% \mathrm{Cr}$ are detected in a $\approx 65 \mu \mathrm{m}$ thick LNF coating on Crofer 22 APU (Figure $6 \mathrm{~b}$ ). This could indicate a slightly more efficient mechanism of chromium trapping in LSMC as compared to LNF related to the formation of $\mathrm{SrCrO}_{4}$. Furthermore, promotion of $(\mathrm{Mn}, \mathrm{Cr})_{3} \mathrm{O}_{4}$ and $(\mathrm{Cr}, \mathrm{Mn}, \mathrm{Co})_{3} \mathrm{O}_{4}$ scale growth in the presence of $\left(\mathrm{La}_{0.8} \mathrm{Sr}_{0.2}\right)\left(\mathrm{Mn}_{0.5} \mathrm{Co}_{0.5}\right) \mathrm{O}_{3-\delta}$ may influence the amount of volatile chromium species, as these spinels have been shown to exhibit lower partial pressures of mobile Cr-species as compared to pure $\mathrm{Cr}_{2} \mathrm{O}_{3}[6,11,21]$. However, neither of these contact coatings is able prevent the transport of chromium over $3000 \mathrm{~h}$ under these conditions.

On K41X substrates, chromium is also present throughout the contact coatings. Due to delamination along the scale and interfacial reaction layers for both LSMC and LNF contact coatings on K41X after $3000 \mathrm{~h}$ of annealing, these values are not quantified.

The amount of chromium transported from steel samples (with or without 
contact coatings) into a SOE anode material (LSM) during annealing for $500 \mathrm{~h}$ at $700^{\circ} \mathrm{C}$ in oxygen was also directly analyzed by the evaporation method described above. The ratio of $\mathrm{Cr} / \mathrm{La}$ measured in the LSM electrodes after annealing at $700^{\circ} \mathrm{C}$ for $500 \mathrm{~h}$ in oxygen is presented in Figure 7 for different combinations of interconnects and contact coatings, including bare steel substrates. Introduction of a contact coating significantly reduces the $\mathrm{Cr}$ content in the oxygen electrode as compared to the bare substrates. In general, slightly less $\mathrm{Cr}$ is detected for the K41X steel than for Crofer, which could reflect the lower Cr content of K41X as compared to Crofer (18wt\% vs. $22 \mathrm{wt} \%$ ). Regarding the contact materials, less chromium is generally detected for LSMC than for LNF coatings in agreement with the previous results obtained by EDS analyses. For longer annealing times, the transport of chromium into the SOE oxygen electrode is expected to be even more significant, given the increased chromium content in contact coatings after $3000 \mathrm{~h}$ (Figure $6 \mathrm{a}, \mathrm{b})$.

Introduction of a dense $(\mathrm{Co}, \mathrm{Mn})_{3} \mathrm{O}_{4}$ spinel coating between steel and contact coating

To further inhibit the transport of chromium resulting in a performance degradation of contact coatings and electrodes, a $(\mathrm{Co}, \mathrm{Mn})_{3} \mathrm{O}_{4}$ spinel coating of 3-4 $\mu \mathrm{m}$ thickness was then added between steel and contact layer. An example is shown and discussed for Crofer $22 \mathrm{APU} /(\mathrm{Co}, \mathrm{Mn})_{3} \mathrm{O}_{4} / \mathrm{LNF}$. According to the BSE image in Figure 8 and the HAADF-STEM overview in Figure 9, the PVD spinel coating forms a dense layer, although isolated pores are present along the steel/ $(\mathrm{Co}, \mathrm{Mn})_{3} \mathrm{O}_{4}$ interface. On annealing at $700^{\circ} \mathrm{C}$ for $3000 \mathrm{~h}$, a $\mathrm{Cr}$ and $\mathrm{O}$ rich layer develops at this interface, in which some $\mathrm{Mn}$ is also present (EDS maps in Figure 8). This crystalline scale layer has a thickness of up to $1 \mathrm{\mu m}$ according to Figure 9. The zero-loss and EFTEM images of $\mathrm{Fe}, \mathrm{Cr}, \mathrm{Mn}$ and $\mathrm{Co}$ in Figure 10 give a more detailed view on the Crofer $22 \mathrm{APU} /(\mathrm{Co}, \mathrm{Mn})_{3} \mathrm{O}_{4}$ interface. According to the distribution of $\mathrm{Cr}$ and $\mathrm{Mn}$, the interfacial scale layer seems to be composed of both $\mathrm{Cr}_{2} \mathrm{O}_{3}$ and $\mathrm{Cr}_{2} \mathrm{MnO}_{4}$ spinels as reported previously $[8,9]$. Furthermore, $\mathrm{Cr}$ is enriched at the surface of isolated pores at the steel/ $(\mathrm{Co}, \mathrm{Mn})_{3} \mathrm{O}_{4}$ interface.

This $(\mathrm{Co}, \mathrm{Mn})_{3} \mathrm{O}_{4}$ coating effectively prevents the transport of $\mathrm{Cr}$ from the steel interconnect into the contact coatings, and $\mathrm{Cr}$ is not detected by EDS linescans through the LNF layer after annealing for $3000 \mathrm{~h}$ at $700^{\circ} \mathrm{C}$ (see Figures $5 \mathrm{~b}$ and $6 \mathrm{c}$ ). Also the evaporation method indicates a further reduction of $\mathrm{Cr}$ in the SOE oxygen electrode in the presence of the $(\mathrm{Co}, \mathrm{Mn})_{3} \mathrm{O}_{4}$ 
coating, which amounts to reductions of $74 \%$ and $78 \%$ on Crofer $22 \mathrm{APU}$ and K41X steels as compared to bare Crofer steel, respectively (Figure 7). Microstructural observations and chemical analyses of the $\mathrm{K} 41 \mathrm{X} /(\mathrm{Co}, \mathrm{Mn})_{3} \mathrm{O}_{4} /$ LNF combination are not shown because of delamination at the steel/ oxide interface.

In view of application in SOE stacks, the aging behavior of the interconnect/ coating combination is of high importance. This includes not only the capacity to trap chromium, but also the adherence of coatings and the overall area specific resistance. For this, not only the properties of the coating materials but also those of the reaction products formed during operation have to be taken into account. In literature [2], a loss of adherence has been reported between $\left(\mathrm{La}_{0.8} \mathrm{Sr}_{0.2}\right)\left(\mathrm{Co}_{0.75} \mathrm{Fe}_{0.25}\right) \mathrm{O}_{3-\delta}$ (LSCF) contact layers and $\mathrm{Co}_{1.9} \mathrm{Fe}_{0.1} \mathrm{MnO}_{4}$ on Crofer due to an insufficient match of the corresponding thermal expansion coefficients (see Table 1). For $\mathrm{MnCo}_{2} \mathrm{O}_{4}$, an even lower TEC of $9.7 \cdot 10^{-6} \mathrm{~K}^{-1}$ has been published [25], while values of $11.1 \cdot 10^{-6} \mathrm{~K}^{-1}$ and $13.2 \cdot 10^{-6} \mathrm{~K}^{-1}$ for $\operatorname{LNF}[29,30]$ and $13.7 \cdot 10^{-6} \mathrm{~K}^{-1}$ for LSMC [31] are found. Nevertheless, the $(\mathrm{Co}, \mathrm{Mn})_{3} \mathrm{O}_{4}$ coatings in this study show good adherence to the Crofer $22 \mathrm{APU}$ substrate also after annealing at $700^{\circ} \mathrm{C}$ for $3000 \mathrm{~h}$ in oxygen according to the SEM and FIB sections. In contrast, delamination was more frequently observed along and within the $(\mathrm{Co}, \mathrm{Mn})_{3} \mathrm{O}_{4}$ protective layer as well as along LSMC and LNF contact coatings on K41X steel. The observed delaminations seem to have occurred upon cooling since no correlation has been observed with the results on chromium transport by the evaporation method. As the TECs of the two steels are quite similar (see Table 1), the formation of reaction products at the interface could be responsible for delamination.

\section{Conclusions}

Even under simulated SOE operating conditions at a relatively mild temperature of $700^{\circ} \mathrm{C}$ without current and in the absence of water vapor on the anode side, chromium transport from steel interconnects into contact coatings is significant. The formation of different scale layers on the surface of K41X (mainly $\mathrm{Cr}_{2} \mathrm{O}_{3}$ ) and Crofer $22 \mathrm{APU}$ (mainly $\mathrm{Cr}_{2} \mathrm{MnO}_{4}$ ) does not significantly influence the transport of chromium, leading to very similar $\mathrm{Cr}$ distributions in the LNF contact layer after $200 \mathrm{~h}$ of annealing, probably in the form of perovskites. In the case of the LSMC coatings, an additional reaction layer with 
a $(\mathrm{Cr}, \mathrm{Mn}, \mathrm{Co})_{3} \mathrm{O}_{4}$ spinel phase surrounding the LSMC particles is formed at the interface, and aggregates with $\mathrm{SrCrO}_{4}$ filling up the pores space around former LSMC particles develop throughout the LSMC layer. These chemical reactions negatively influence the ionic and electronic conductivity of the contact materials (as well as their gas diffusion properties in terms of aggregates). Furthermore, the trapping of chromium species in the porous contact layers by chemical reactions does not prevent the transport of chromium into adjacent electrodes for more than a few hundred hours at $700^{\circ} \mathrm{C}$, and further transport is expected with time. This shows that the application of chromium diffusion barriers on steel interconnects is essential also for operation at $700^{\circ} \mathrm{C}$ in dry oxygen. The introduction of a dense $(\mathrm{Co}, \mathrm{Mn})_{3} \mathrm{O}_{4}$ protective layer is able to reduce the amount of chromium in a $\mathrm{SOE}$ oxygen electrode by more than $70 \%$ after $500 \mathrm{~h}$ at $700^{\circ} \mathrm{C}$ according to an evaporation study, and chromium is not detected in the contact layer even after 3000h. The $(\mathrm{Co}, \mathrm{Mn})_{3} \mathrm{O}_{4}$ protective layer should thus avoid the poisoning of anode and contact coatings, leading to extended stack performance and lifetime.

\section{Acknowledgments}

The research leading to these results has received funding from the European Union's Seventh Framework Programme (FP7/2007-2013) for the Fuel Cells and Hydrogen Joint Technology Initiative under grant agreement $\mathrm{n}^{\circ}$ 256755. The authors thank Seul Cham Kim, Yong Seok Choi and Kyu Hwan Oh, Department of Materials Science and Engineering, Seoul National University, Seoul 151-744, Republic of Korea for support and the use of their microscopy facilities. We also thank Nathalie Giacometti, Richard Laucournet, Myriam Dalmasso and Nathalie Diafera, Laboratory for Innovation in New Energy Technologies and Nanomaterials (LITEN), Commissariat à l'énergie atomique et aux énergies alternatives (CEA), 38054 Grenoble, France for coating of the samples by screen-printing and for evaporation testing, including ICP-OES analyses.

\section{References}

[1] Z. G. Yang, J. S. Hardy, M. S. Walker, G. G. Xia, S. P. Simner, J. W. Stevenson, J. Electrochem. Soc. 151 (2004) A1825-A1831.

[2] X. Montero, F. Tietz, D. Sebold, H. Buchkremer, A. Ringuede, M. Cassir, A. Laresgoiti, I. Villarreal, J. Power Sources 184 (2008) 172-179. 
[3] M. Linder, T. Hocker, L. Holzer, K. A. Friedrich, B. Iwanschitz, A. Mai, J. A. Schuler, J. Power Sources 243 (2013) 508-518.

[4] S. Guillou, C. Desgranges, S. Chevalier, Oxid. Met. 79 (2013) 507-516.

[5] M. R. Ardigo, I. Popa, S. Chevalier, V. Parry, A. Galerie, P. Girardon, F. Perry, R. Laucournet, A. Brevet, E. Rigal, Int. J. Hydrogen Energy 38 (2013) 15910-15916.

[6] E. Konysheva, H. Penkalla, E. Wessel, J. Mertens, U. Seeling, L. Singheiser, K. Hilpert, J. Electrochem. Soc. 153 (2006) A765-A773.

[7] S. H. Hong, M. P. Phaniraj, D.-I. Kim, J.-P. Ahn, Y. W. Cho, S. H. Han, H. N. Han, Electrochem. Solid-State Lett. 13 (2010) B40-B42.

[8] J. Froitzheim, S. Canovic, M. Nikumaa, R. Sachitanand, L. G. Johansson, J. E. Svensson, J. Power Sources 220 (2012) 217-227.

[9] N. J. Magdefrau, L. Chen, E. Y. Sun, J. Yamanis, M. Aindow, J. Power Sources 227 (2013) 318-326.

[10] K. Hilpert, D. Das, M. Miller, D. H. Peck, R. Weiss, J. Electrochem. Soc. 143 (1996) 3642-3647.

[11] M. Stanislowski, J. Froitzheim, L. Niewolak, W. J. Quadakkers, K. Hilpert, T. Markus, L. Singheiser, J. Power Sources 164 (2007) 578589.

[12] Y. Matsuzaki, I. Yasuda, J. Electrochem. Soc. 148 (2001) A126-A131.

[13] J. R. Mawdsley, J. David Carter, A. Jeremy Kropf, B. Yildiz, V. A. Maroni, Int. J. Hydrogen Energy 34 (2009) 4198-4207.

[14] T. Horita, D.-H. Cho, F. Wang, T. Shimonosono, H. Kishimoto, K. Yamaji, M. E. Brito, H. Yokokawa, Solid State Ionics 225 (2012) 151-156.

[15] K. Fujita, K. Ogasawara, Y. Matsuzaki, T. Sakurai, J. Power Sources 131 (2004) 261-269.

[16] R. Trebbels, T. Markus, L. Singheiser, J. Fuel Cell Sci. Technol. 7 (2010) 011013. 
[17] W. N. Liu, X. Sun, E. Stephens, M. A. Khaleel, J. Power Sources 189 (2009) 1044-1050.

[18] Z. Yang, G.-G. Xia, G. D. Maupin, J. W. Stevenson, Surf. Coat. Technol. 201 (2006) 4476-4483.

[19] R. Lacey, A. Pramanick, J. C. Lee, J.-I. Jung, B. Jiang, D. D. Edwards, R. Naum, S. T. Misture, Solid State Ionics 181 (2010) 1294-1302.

[20] C. Gindorf, L. Singheiser, K. Hilpert, Steel Research 72 (2001) 528-533.

[21] J. Froitzheim, H. Ravash, E. Larsson, L. G. Johansson, J. E. Svensson, J. Electrochem. Soc. 157 (2010) B1295-B1300.

[22] ThyssenKrupp VDM, Material Data Sheet No.4046 Crofer 22 APU (2010) 1-12.

[23] X. Montero, F. Tietz, D. Stöver, M. Cassir, I. Villarreal, J. Power Sources 188 (2009) 148-155.

[24] X. Chen, P. Y. Hou, C. P. Jacobson, S. J. Visco, L. C. De Jonghe, Solid State Ionics 176 (2005) 425-433.

[25] A. Petric, H. Ling, J. Am. Ceram. Soc. 90 (2007) 1515-1520.

[26] K. Wang, Y. Liu, J. W. Fergus, J. Am. Ceram. Soc. 94 (2011) 4490-4495.

[27] W. Li, K. Lu, Z. Xia, J. Power Sources 237 (2013) 119-127.

[28] K. Fujita, T. Hashimoto, K. Ogasawara, H. Kameda, Y. Matsuzaki, T. Sakurai, J. Power Sources 131 (2004) 270-277.

[29] R. Chiba, F. Yoshimura, Y. Sakurai, Solid State Ionics 124 (1999) 281288.

[30] S. P. Simner, J. F. Bonnett, N. L. Canfield, K. D. Meinhardt, V. L. Sprenkle, J. W. Stevenson, Electrochem. Solid-State Lett. 5 (2002) A173-A175.

[31] S. Kuharuangrong, T. Dechakupt, P. Aungkavattana, Materials Letters 58 (2004) 1964-1970.

[32] Aperam Stainless Europe, Technical data sheet KARA ferritic stainless steel offer: grade K41 (2012) 1-4. 


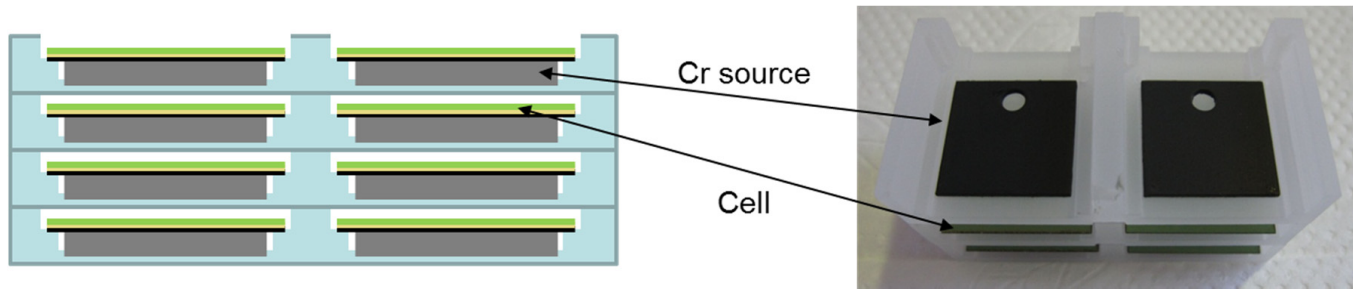

Figure 1: Schematic and photograph of the quartz sample-holder for Cr evaporation testing.

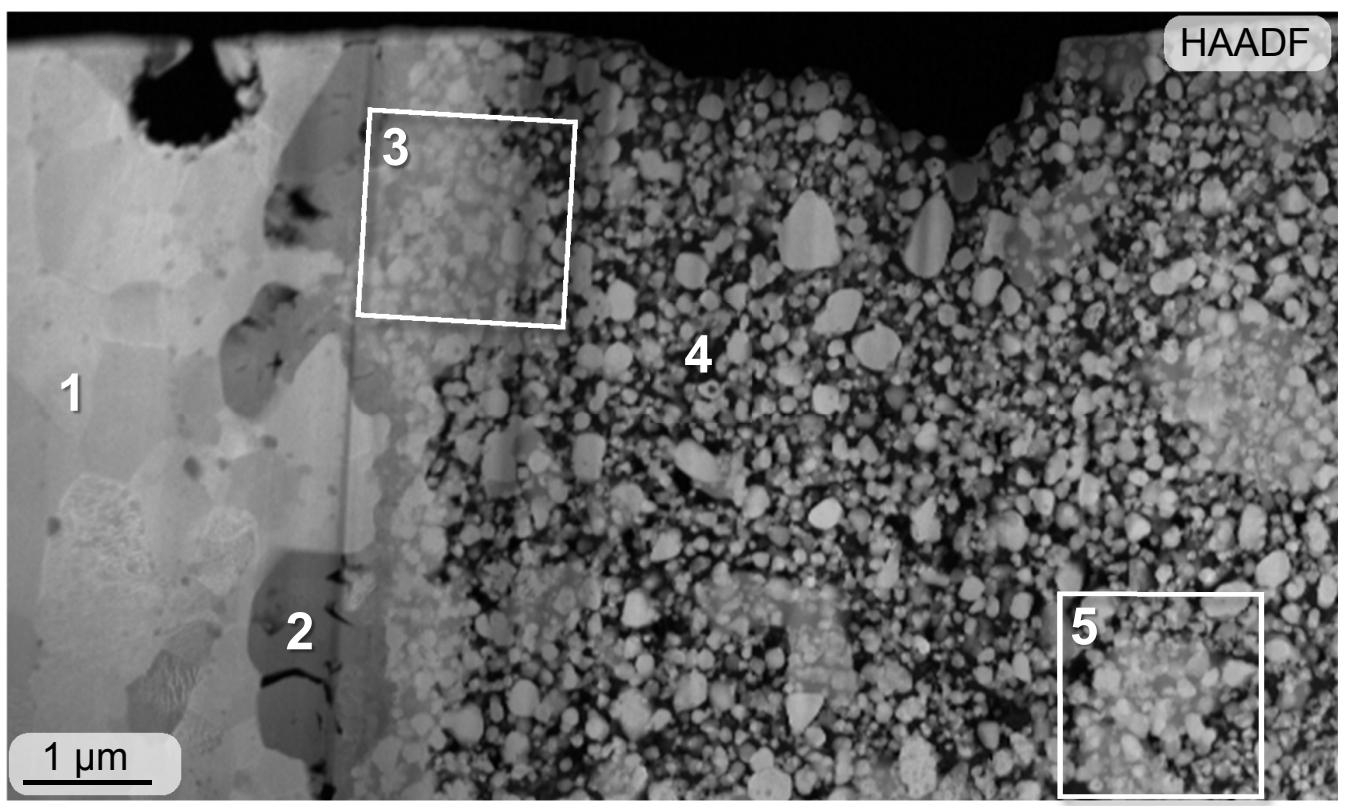

Figure 2: HAADF-STEM overview of a Crofer/ LSMC interface after annealing at $700^{\circ} \mathrm{C}$ for $3000 \mathrm{~h}$ (FIB lamella). (1) Crofer $22 \mathrm{APU}$ steel, (2) $\mathrm{Cr}_{2} \mathrm{MnO}_{4}$ spinel scale, (3) $(\mathrm{Cr}, \mathrm{Mn}, \mathrm{Co})_{3} \mathrm{O}_{4}$ spinel around LSMC particles, (4) LSMC, (5) amorphous $\mathrm{SrCrO}_{4}$ around former LSMC particles. 


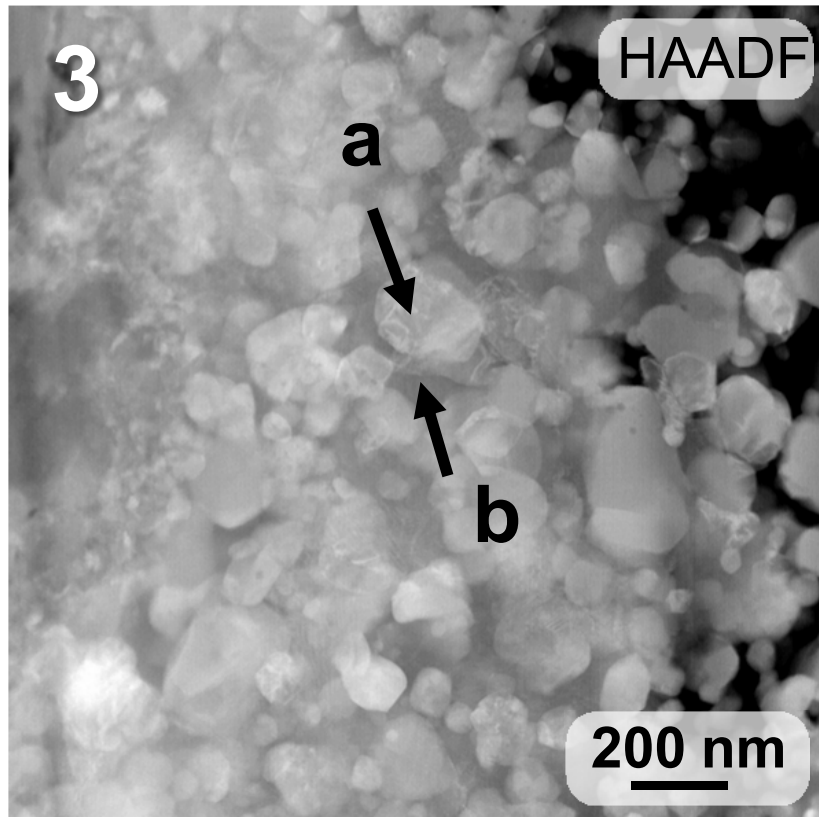

Figure 3: HAADF-STEM image of position 3 in Figure 2. EDS shows the presence of $\mathrm{La}, \mathrm{Sr}, \mathrm{Mn}, \mathrm{Co}$ and $\mathrm{O}$ (LSMC) at location a, and of Co, Mn, Cr and $\mathrm{O}$ at location b $\left((\mathrm{Co}, \mathrm{Mn}, \mathrm{Cr})_{3} \mathrm{O}_{4}\right)$. Both phases are crystalline according to HR-TEM. 

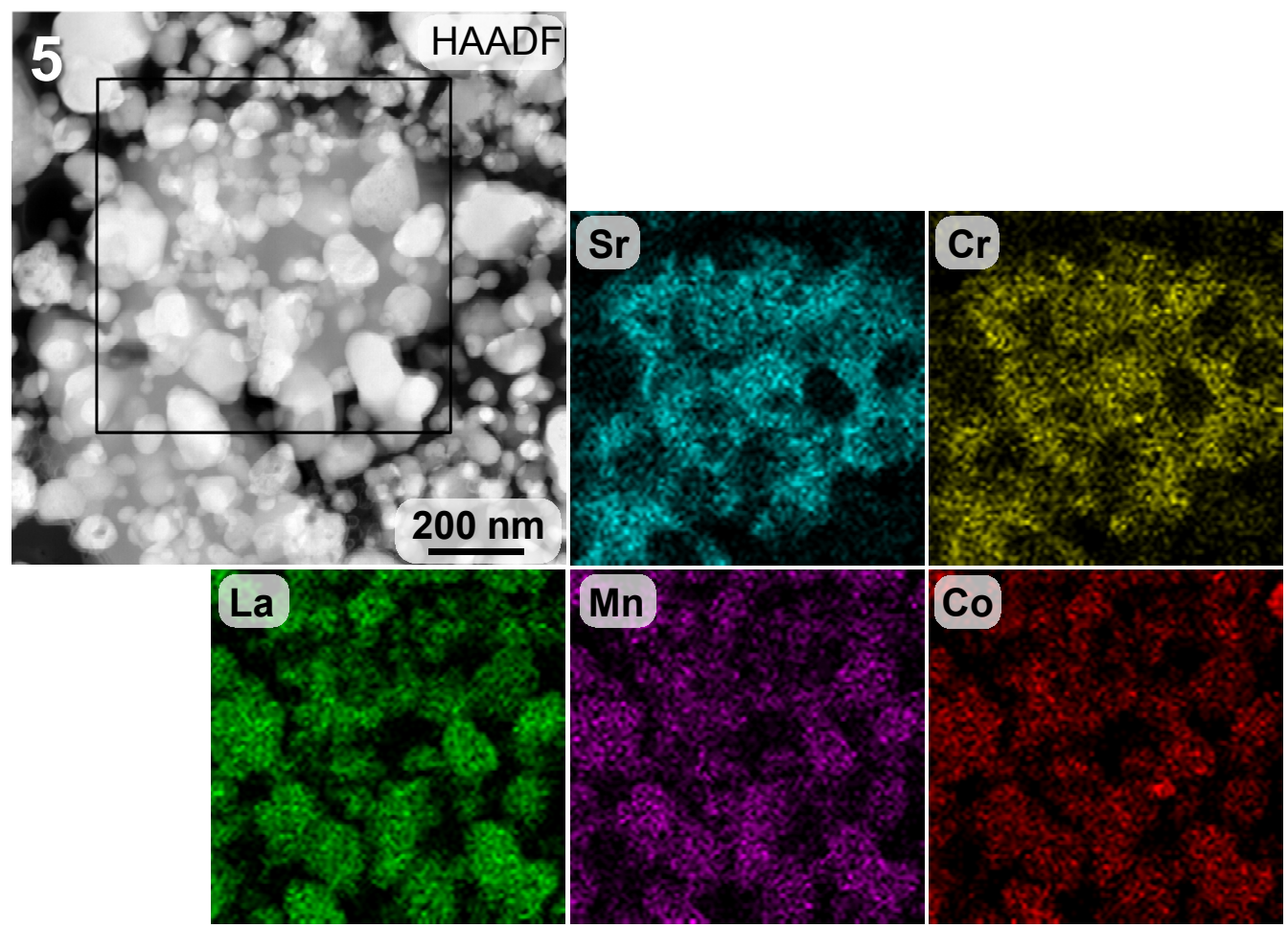

Figure 4: HAADF-STEM image of position 5 in Figure 2 and corresponding EDS maps of $\mathrm{Sr}, \mathrm{Cr}, \mathrm{La}, \mathrm{Mn}$, and Co.
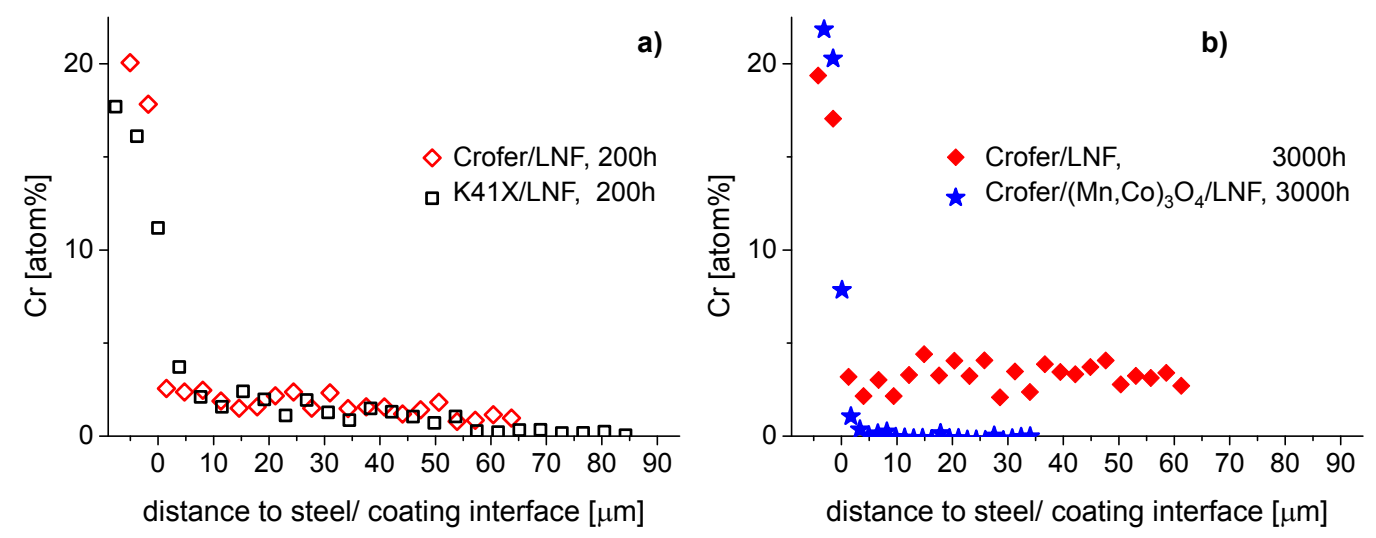

Figure 5: Cr content detected by EDS linescans on polished sections of a) LNF contact coatings deposited directly on Crofer 22 APU or K41X steel substrates after annealing at $700^{\circ} \mathrm{C}$ for $200 \mathrm{~h}$, and b) LNF contact coatings deposited on Crofer 22 APU steel substrates with and without a $(\mathrm{Mn}, \mathrm{Co})_{3} \mathrm{O}_{4}$ coating after annealing at $700^{\circ} \mathrm{C}$ for $3000 \mathrm{~h}$. 

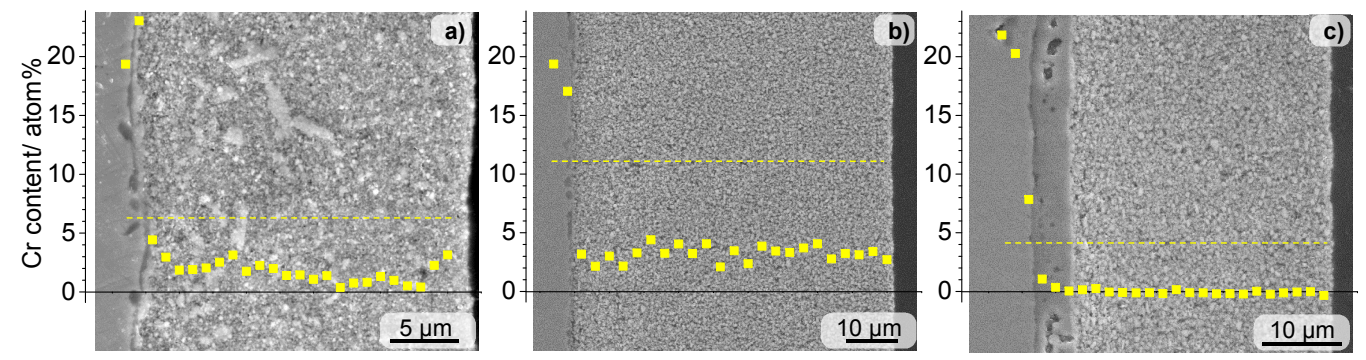

Figure 6: Cr content detected by EDS linescans (along the dotted lines) on polished sections of a) LSMC, b) LNF and c) $(\mathrm{Co}, \mathrm{Mn})_{3} \mathrm{O}_{4} /$ LNF contact coatings deposited on Crofer 22 APU steel substrates after annealing at $700^{\circ} \mathrm{C}$ for $3000 \mathrm{~h}$; overlay with backscattered electron images. The bright agglomerates in a) correspond to a $\mathrm{SrCrO}_{4}$ phase surrounding former LSMC particles.

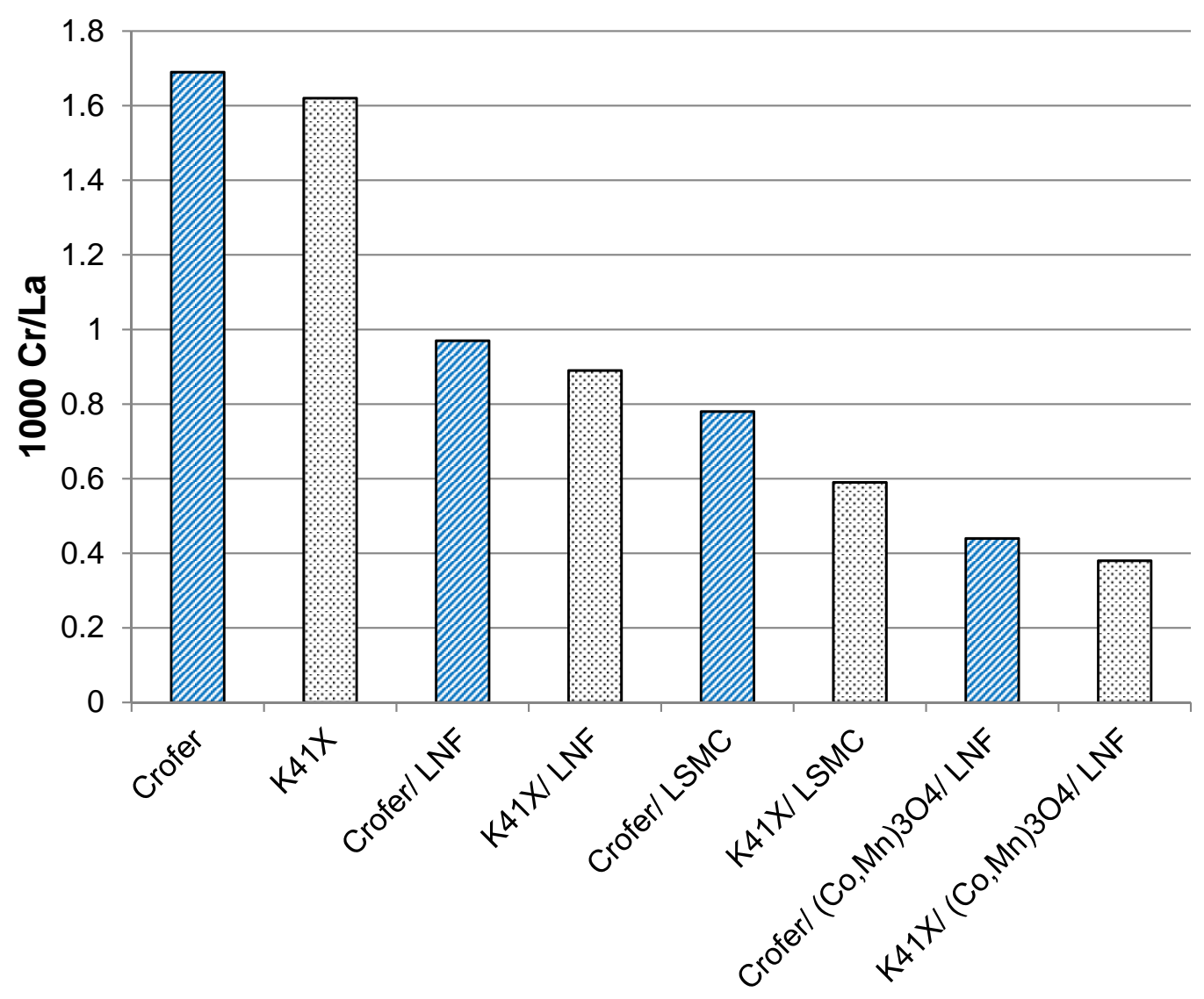

Figure 7: $\mathrm{Cr} / \mathrm{La}$ ratios measured by ICP-OES after $500 \mathrm{~h}$ at $700^{\circ} \mathrm{C}$ in a LSM layer facing the different interconnect/ coating combinations. 


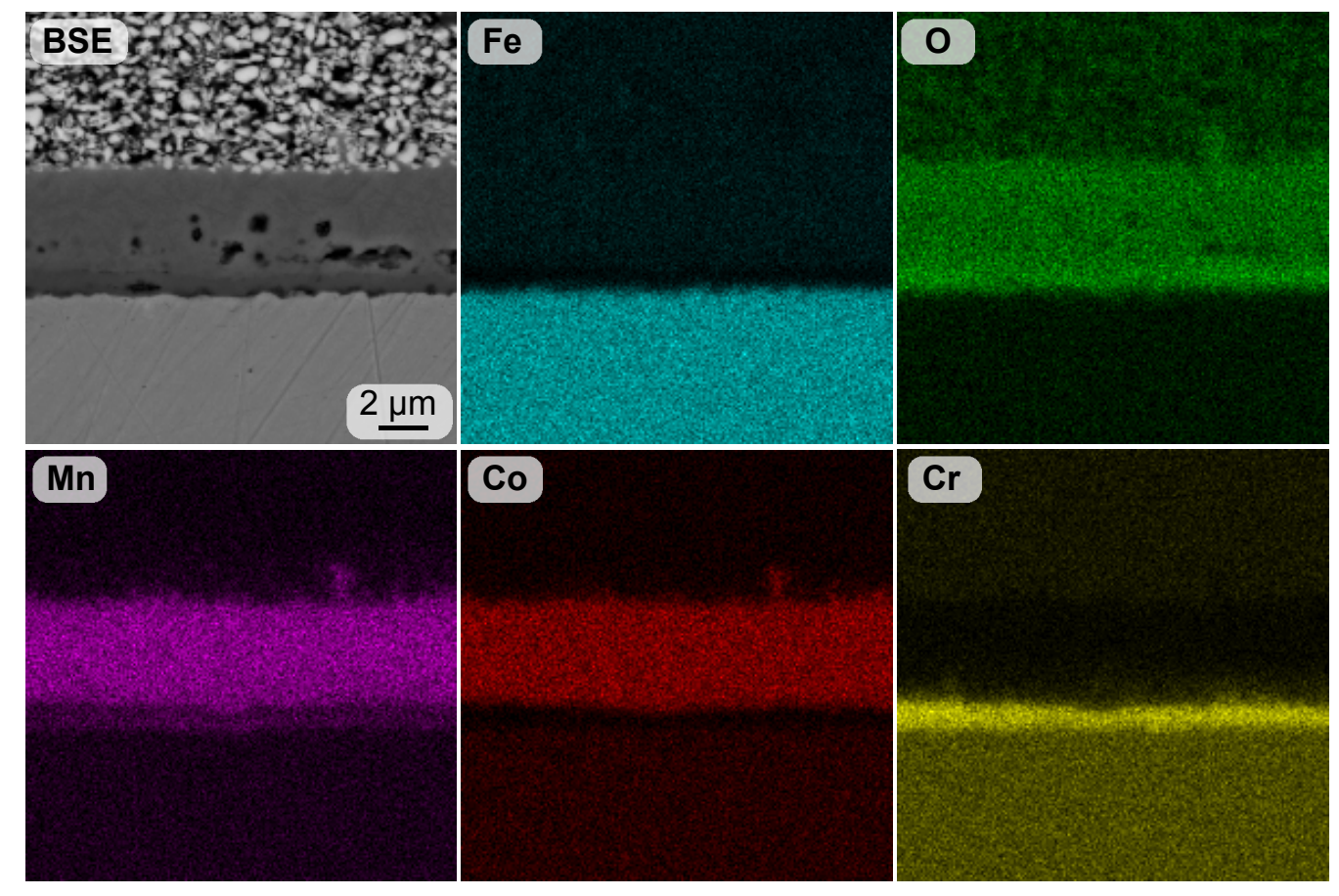

Figure 8: BSE image and EDS maps (Fe, O, Mn, Co and $\mathrm{Cr}$ ) of the Crofer $/(\mathrm{Mn}, \mathrm{Co})_{3} \mathrm{O}_{4} / \mathrm{LNF}$ interfaces after annealing at $700^{\circ} \mathrm{C}$ for $3000 \mathrm{~h}$ (polished cross section). 


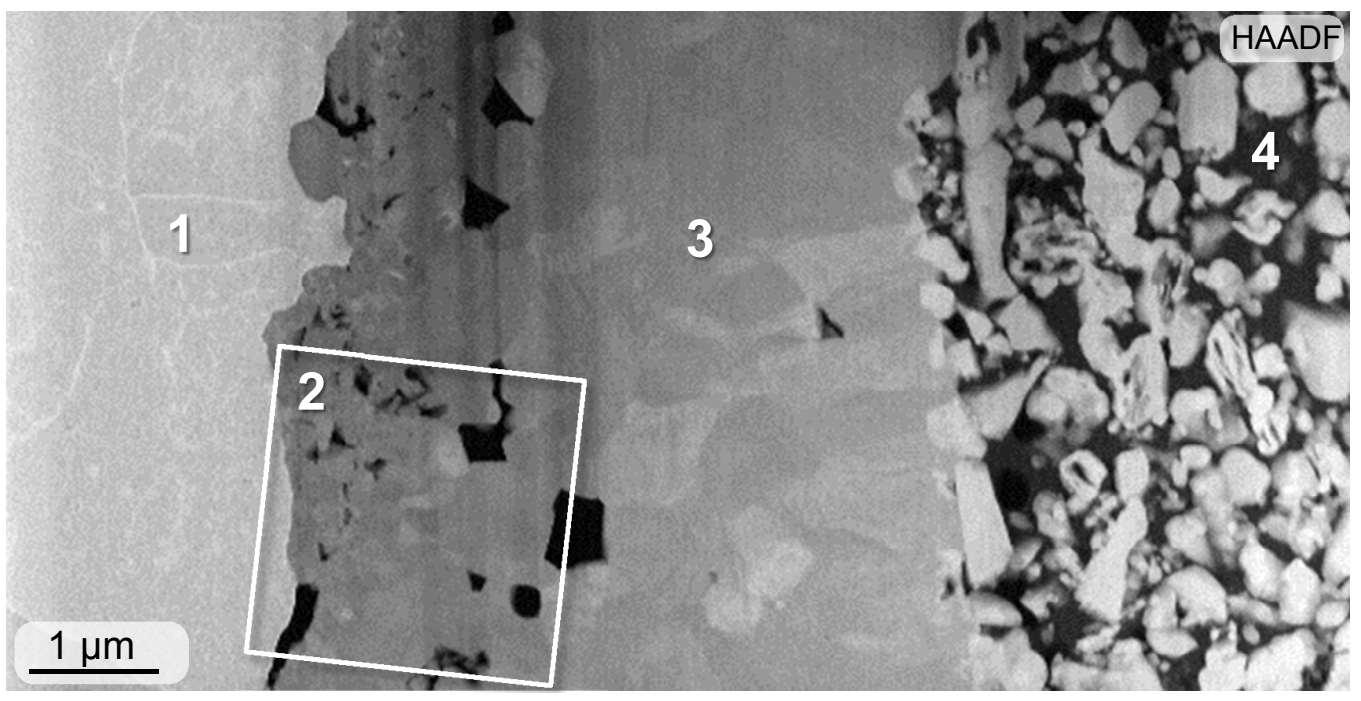

Figure 9: HAADF-STEM overview of the Crofer/ $(\mathrm{Mn}, \mathrm{Co})_{3} \mathrm{O}_{4} / \mathrm{LNF}$ interfaces after annealing at $700^{\circ} \mathrm{C}$ for $3000 \mathrm{~h}$ (FIB lamella). (1) Crofer $22 \mathrm{APU}$ steel, (2) $\mathrm{Cr}_{2} \mathrm{MnO}_{4} / \mathrm{Cr}_{2} \mathrm{O}_{3}$ scale, (3) $(\mathrm{Mn}, \mathrm{Co})_{3} \mathrm{O}_{4}$ spinel coating, (4) LNF.

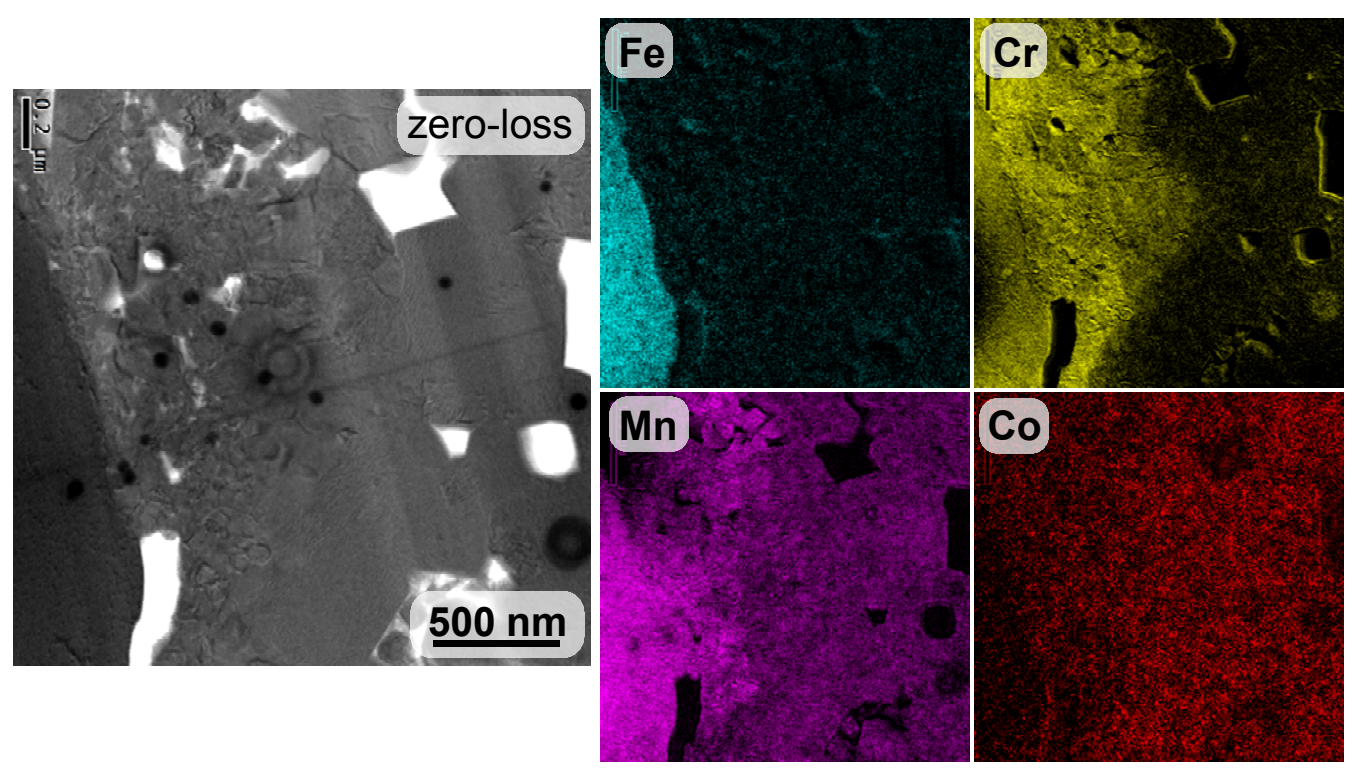

Figure 10: Zero-loss image of Crofer/ $(\mathrm{Mn}, \mathrm{Co})_{3} \mathrm{O}_{4}$ interface (position 2 in Figure 9) and corresponding EFTEM maps of Fe, Cr, Mn and Co. 
Table 1: Thermal expansion coefficients (TECs) of steels and coatings reported in literature.

\begin{tabular}{l|l} 
material & TEC $\left[10^{-6} \mathrm{~K}^{-1}\right]$ \\
\hline Crofer 22 APU & $11.9\left(20-800^{\circ} \mathrm{C}\right)[22]$ \\
K41X & $12.8\left(20-800^{\circ} \mathrm{C}\right)[32]$ \\
$\mathrm{Co}_{1.9} \mathrm{Fe}_{0.1} \mathrm{MnO}_{4}$ & $13.4\left(30-800^{\circ} \mathrm{C}\right)[2]$ and refs. therein \\
$\mathrm{Co}_{2} \mathrm{MnO}_{4}$ & $9.7\left(20-800^{\circ} \mathrm{C}\right)[25]$ \\
$\mathrm{LSCF}$ & $19\left(30-800^{\circ} \mathrm{C}\right)[2]$ and refs. therein \\
LSMC & $13.7\left(100-900^{\circ} \mathrm{C}\right)[31]$ \\
LNF & $11.1\left(30-800^{\circ} \mathrm{C}\right)[29], 13.2\left(30-1000^{\circ} \mathrm{C}\right)[30]$ \\
\hline
\end{tabular}

